PREGLEDNI RAD - REVIEW

\title{
Aminoglikozidni antibiotici - primjena u veterinarstvu i kontrola u hrani životinjskog podrijetla
}

\section{Aminoglycoside antibiotics - application in veterinary and control in food of animal origin}

\author{
Liridone Fejzuli', Božica Solomun Kolanović², Jagoda Šušković1, Blaženka Kos ${ }^{1 *}$, Nina Bilandžić \\ Laboratorij za tehnologiju antibiotika, enzima, probiotika i starter kultura, Zavod za biokemijsko inženjerstvo, Prehram- \\ beno-biotehnološki fakultet Sveučilišta u Zagrebu, Pierottijeva 6, 10000 Zagreb, Hrvatska \\ ${ }^{2}$ Laboratorij za određivanje rezidua, Odjel za veterinarsko javno zdravstvo, Hrvatski veterinarski institut, Savska 143, 10 \\ 000 Zagreb, Hrvatska \\ *Corresponding author: bkos@pbf.hr
}

\section{Sažetak}

Aminoglikozidni antibiotici se upotrebljavaju u terapiji bolesti, kao aditivi stočnoj hrani, ili kao promotori rasta kako bi se poticao rast životinja. Dio apliciranih antibiotika se akumulira unutar različitih tkiva, a dio se izlučuje kroz urin, izmet, mlijeko i jaja tretiranih životinja, bilo kao nemetabolizirani ishodišni spojevi, ili kao njihovi metaboliti. To može predstavljati stvarnu prijetnju potrošaču, kroz izloženost ostacima antibiotika, a moguć je razvoj i prijenos antibiotičke rezistencije ili pojava alergija i drugih zdravstvenih poremećaja. Negativni aspekti uporabe antibiotika kod životinja potvrđuju važnost kontinuiranog praćenja ostataka antibiotika, kao i razvoja učinkovitih analitičkih tehnika za utvrđivanje njihove bioakumulacije u tkivima i precizne koncentracije ostataka antibiotika u proizvodima životinjskog podrijetla namijenjenih ljudskoj prehrani.

Ključne riječi: antibiotici, aminoglikozidi, antibiotička rezistencija, hrana životinjskog podrijetla, kontrola hrane

Abstract

Aminoglycoside antibiotics are used for disease control, as feed additives, or as growth promoters in order to improve feed utilization and animal production. Applied antibiotics are partly accumulated in various tissues and partly excreted via urine, feces, milk and eggs of treated animals as non-metabolized parent compounds or as their metabolites. This may pose a real threat to the consumer, either through exposure to the antibiotic residues, or through the development and transfer of antibiotic resistance and occurrence of allergies and other health disturbances. The negative aspects of the use of antibiotics in animal diets confirm the importance of continuous monitoring of antibiotic residues in both live animals and animal products, and importance of the development of effective analytical techniques to determine their bioaccumulation in animal tissues and the precise concentrations of antibiotic residues in food products of animal origin.

Keywords: antibiotics, aminoglycosides, antibiotic resistance, food of animal origin, food control

\section{Uvod}

Aminoglikozidi (AG) su jedna od najranije otkrivenih skupina antibiotika i prvi otkriveni antibiotici širokog spektra djelovanja (Šušković i Kos, 2017). Prvi otkriveni AG bio je streptomicin, 1943. godine, kojeg proizvodi bakterijska vrsta Streptomyces griseus. U sljedeća dva desetljeća, mnogi drugi aminoglikozidi su izolirani iz bakterija tla, koje pripadaju koljenu Actinobacteria (kanamicin, spektinomicin, tobramicin, neomicin, apramicin) (Šušković i sur., 2017). Aminoglikozidi imaju širok antibakterijski spektar i pokazuju najveću učinkovitost u liječenju infekcija uzrokovanih aerobnim i fakultativno anaerobnim Gram-negativnim bakterijama. Općenito su manje djelotvorni protiv Gram-pozitivnih bakterija, osobito streptokoka. Njihova aktivnost je nedovoljna kada se koriste kao monoterapija protiv streptokoka ili enterokoka. Stoga je klinička primjena aminoglikozida u liječenju Gram-pozitivnih bakterijskih infekcija općenito ograničena na sinergističke kombinacije s drugim antibioticima. Razvoj rezistencije prema aminoglikozidima kao i njihova relativna toksičnost potaknuli su razvoj poboljšanih derivata aminoglikozida (amikacin, netilmicin, isepamicin, dibekacin i arbekacin) i mimetika (Vakulenko i Mobashery, 2003). Poznavanje mehanizma djelovanja aminoglikozida dovelo je, od sredine 1990-ih, do nove primjene ovih lijekova za eksperimentalno liječenje genetičkih poremećaja, uključujući cističnu fibrozu i Duchenneovu mišićnu distrofiju (Zingman i sur., 2007). 
Aminoglikozidi se, kao i drugi antibiotici, često koriste, ne samo za terapiju bolesti, nego i kao prehrambeni aditivi ili sintetski promotori rasta životinja (stočarstvo, peradarstvo, akvakultura) kako bi se poboljšala iskoristivost hrane te poticao rast životinja (Fisher i sur., 2011). Veliki dio apliciranog antibiotika se izlučuje kroz urin i izmet (Ostermann i sur., 2013), mlijeko (Arikan i sur., 2009) i jaja (Idowu i sur., 2010), dok se ostatak akumulira u različitim tkivima (Kwon i sur., 2011). Česta primjena antibiotika dovodi do razvoja i prijenosa gena za antibiotičku rezistenciju kod bakterija što predstavlja opasnost za potrošače (Butaye i sur., 2003). Ostaci antibiotka u hrani životinjskog podrijetla mogu izazivati povišene stope alergija (Ronquillo i Hernandez, 2017).

Tijekom posljednjih desetljeća potrošači su postali svjesni važnosti upravljanja sigurnošću hrane tijekom procesa proizvodnje prehrambenih proizvoda. Europska komisija je u svrhu zaštite zdravlja potrošača uspostavila agencije za sigurnost hrane u mnogim državama članicama Europske unije (EU), odnosno Upravu za zdravstvo i zaštitu potrošača te Europsku agenciju za sigurnost hrane (Vandenberge, 2012). Postoji mnogo odobrenih antimikrobnih supstancije koje se mogu klasificirati kao veterinarski lijekovi za kontrolu i prevenciju bolesti te kao promotori rasta koji se često primjenjuju putem vode ili aditiva u hrani za životinje. Kontrole uporabe veterinarskih lijekova, uključujući tvari za promicanje rasta kod životinja, strogo su regulirane od strane EU mnogobrojnim propisima i direktivama. Od 1998. godine EU je zabranila uporabu antibiotika u prehrambenim proizvodima (Stolker i sur., 2007). Zabrinutost zbog razvoja antibiotičke otpornosti i prijenosa gena za rezistenciju na antibiotike s animalne na humanu mikrobiotu prisilila je Europsku komisiju da od prvog siječnja 2006. godine odstrani i eventualno zabrani marketing te uporabu antibiotika kao promotora rasta u hrani namijenjenoj životinjama primjenom Uredbe 1831/2003 (EC, 2003). Treba napomenuti da je uporaba promotora rasta u mnogim dijelovima svijeta još uvijek uobičajena praksa (Castanon, 2007). Sve navedeno upućuje na važnost razvoja učinkovitih analitičkih metoda za određivanje prisutnosti antibiotika u proizvodima životinjskog podrijetla te razinu bioakumulacije i vrijeme zadržavanja antibiotika u tkivima životinja nakon njihove primjene (Fejzuli, 2017).

\section{Struktura, osnovna svojstva i mehanizam djelovanja aminoglikozida}

Aminoglikozidi su spojevi čija se osnovna struktura sastoji od aminociklitolnog prstena zasićenog amino i hidroksilnim skupinama. Kod većine aminoglikozidnih antibiotika, ovaj aminociklitolni dio čini streptamin, odnosno 2-deoksistreptamin. Streptomicin, koji u svojoj strukturi ima molekulu streptidina, je jedini izuzetak. Aminociklitolna jezgra povezana je glikozidnim vezama s različitim aminošećerima, prema kojima se pojedini aminoglikozidi mogu međusobno razlikovati (Ristuccia i Cuncha, 1982). Aminoglikozidi su bazični, jako polarni spojevi koji su pozitivno nabijeni. Dobro su topljivi u vodi, relativno netopljivi u lipidima i imaju pojačanu antimikrobnu aktivnost $\mathrm{u}$ alkalnim, ali ne i kiselim sredinama (Spelman i sur., 1989). Mogu se vezati na negativno nabijene lipopolisaharide te intracelularne $i$ anionske molekule stanične membrane bakterija. Međutim, njihov pozitivan naboj pri fiziološkom $\mathrm{pH}$ pridonosi njihovom nefrotoksičnom i ototoksičnom djelovanju, te može dovesti do pojave neuromuskularne blokade (Gilbert, 1995).

Prednosti terapijske upotrebe aminoglikozida proizlaze iz vrlo male propusnosti eukariotskih stanica za ove antibiotike koji su pod fiziološkim uvjetima pozitivno nabijeni. Aminoglikozidi su bakteriocidne tvari koje inhibiraju sintezu proteina i ometaju integritet bakterijske stanične membrane kroz složeni, višestupanjski proces. Prvotno se kao kationski spojevi elektrostatskim interakcijama vežu na negativno nabijene ostatke u vanjskoj membrani Gram-negativnih bakterija. Zatim difundiraju kroz pore vanjske membrane i ulaze u periplazmatski prostor. Za njihov transport kroz citoplazmatsku membranu potrebna je metabolička energija iz elektron-transportnog sustava koji je ovisan o prisutnosti kisika. Jednom kada uđu u stanicu, aminoglikozidi ometaju translaciju vezanjem za ribosomalno mjesto „A“ na 30S RNA podjedinici ribosoma. Pretpostavlja se da aminoglikozidi reorganiziraju mjesto dekodiranja namijenjeno za vezanje mRNA-tRNA, uzrokujući pogrešno čitanje kodona i inhibiciju translokacije. Kao posljedica toga, dolazi do ometanja procesa translacije što u konačnici dovodi do smrti bakterijske stanice (Ogle i sur., 2001, Ogle i Ramakrishnan, 2005, Blair i sur. 2015).

\section{Primjena aminoglikozida}

Antibiotici se kod životinja upotrebljavaju u tri glavne svrhe: terapijska upotreba za liječenje zaraznih bolesti, profilaktička upotreba za prevenciju zaraznih bolesti te upotreba kao prehrambenih aditiva kod uzgoja životinja (Fisher i sur., 2011). Terapijsko liječenje se oslanja na primjenu aktivne koncentracije antibiotika koja premašuje minimalnu inhibicijsku koncentraciju (MIC, eng. minimum inhibitory concentracion) za patogene mikroorganizme, kroz učinkovito vremensko razdoblje. Prehrambeni aditivi su definirani kao tvari koje poboljšavaju svojstva hrane namijenjene životinjama te potiču njihov rast. Prema Van Boeckelu i sur. (2015.) pet zemalja s najvećim udjelom globalne potrošnje antibiotika za tretiranje životinja: Kina (23\%), Sjedinjene Američke Države (13\%), Brazil (13 \%), Indija (3 \%) i Njemačka (3 \%). Aminoglikozidi se upotrebljavaju u različitim životinjskim vrstama i u različite terapijske svrhe (Tablica 1). 
Tablica 1. Uporaba aminoglikozida u veterinarstvu (EMA/ESVAC, 2016)

Table 1. Application of aminoglycosides in veterinary (EMA/ESVAC, 2016)

\begin{tabular}{|c|c|c|c|c|}
\hline $\begin{array}{l}\text { Aminoglikozidni } \\
\text { antibiotik }\end{array}$ & $\begin{array}{l}\text { Primijenjena } \\
\text { masa/t (ES- } \\
\text { VAC, 2014) }\end{array}$ & $\begin{array}{l}\text { Trajanje } \\
\text { primjene/ } \\
\text { dani }\end{array}$ & $\begin{array}{l}\text { Domaće } \\
\text { životinje }\end{array}$ & Bolest \\
\hline Kanamicin & $<2$ & $3-4$ & stoka & $\begin{array}{l}\text { mastitis uzrokovan Gram-negativnim bakterijama, } \\
\text { septikemija, } \\
\text { infekcije respiratornog i mokraćnog sustava }\end{array}$ \\
\hline Gentamicin & 12 & $3-5$ & $\begin{array}{l}\text { konji } \\
\text { telad i } \\
\text { druge } \\
\text { domaće } \\
\text { životinje }\end{array}$ & $\begin{array}{l}\text { infekcije oka, respiratornog i probavnog sustava, } \\
\text { Septikemija, } \\
\text { metritis }\end{array}$ \\
\hline Amikacin & $<1$ & / & konji & $\begin{array}{l}\text { septikemija. } \\
\text { metritis }\end{array}$ \\
\hline Apramicin & 21 & $\begin{array}{l}5-7 \text { (voda) } \\
28 \text { (stočna } \\
\text { hrana) }\end{array}$ & $\begin{array}{l}\text { perad } \\
\text { svinje } \\
\text { telad }\end{array}$ & $\begin{array}{l}\text { infekcije probavnog sustava bakterijama iz porodice } \\
\text { Enterobacteriaceae }\end{array}$ \\
\hline Streptomicin & 7 & 3 & $\begin{array}{l}\text { perad } \\
\text { stoka } \\
\text { svinje } \\
\text { ovce } \\
\text { konji } \\
\text { psi }\end{array}$ & leptospiroza \\
\hline $\begin{array}{l}\text { Dihidrostrepto- } \\
\text { micin }\end{array}$ & 129 & $3-5$ & \multirow{3}{*}{$\begin{array}{l}\text { svinje } \\
\text { telad } \\
\text { perad }\end{array}$} & $\begin{array}{l}\text { mastitis uzrokovan Gram-negativnim bakterijama, } \\
\text { infekcije probavnog i respiratornog sustava }\end{array}$ \\
\hline Spektinomicin & 70 & 7 & & infekcije probavnog i respiratornog sustava \\
\hline Paramomicin & 18 & $3-5$ & & $\begin{array}{l}\text { histomonijaza, } \\
\text { infekcije probavnog sustava }\end{array}$ \\
\hline Neomicin & 155 & $3-5$ & $\begin{array}{l}\text { domaće } \\
\text { životinje }\end{array}$ & $\begin{array}{l}\text { infekcije probavnog sustava, oka i uha (Enterobacteria- } \\
\text { ceae), } \\
\text { septikemija }\end{array}$ \\
\hline
\end{tabular}

Prema drugom zajedničkom izvješću ECDC/EFSA/EMA (eng. European Center for Disease Prevention and Control/ European Food Safety Authority/ European Medicines Agency) o integriranoj analizi potrošnje antimikrobnih sredstava i pojavi antimikrobne otpornosti u humanim i životinjskim bakterijama „JIACRA“ (eng. Joint Interagency Antimicrobical Consumption and Resistance Analysis - JIACRA report), prodaja aminoglikozida za animalnu upotrebu unutar 28 zemalja iznosila je, izraženo u mg prodanih aminoglikozida po kg procijenjene biomase za životinje, odnosno u mg prodanih aminoglikozida po $\mathrm{kg}$ procijenjene tjelesne mase $5,2 \mathrm{mg} / \mathrm{PCU}$ za životinje i $0,2 \mathrm{mg} / \mathrm{PCU}$ za ljude (PCU - eng. population correction unit) (ECDC/EFSA/EMA, 2017). Aminoglikozidni antibiotici koji su prijavljeni kao prodavani, u sklopu ESVAC (eng. European Surveillance of Veterinary Antimicrobial Consumption) projekta iz 2017. godine, su: amikacin, apramicin, (dihidro)streptomicin, framicetin, gentamicin, kanamicin, neomicin, spektinomicin i paromomicin. Treba napomenuti da za amikacin nije utvrđena najviša dopuštena količina (NDK) te se stoga ne može koristiti kod životinja namijenjenih za proizvodnju hrane. Najčešća primjena aminoglikozida je kod liječenja septikemije, infekcija probavnog trakta, respiratornog trakta te mokraćnog sustava kod različitih vrsta životinja. Aminoglikozidi se često upotrebljavaju u kombinaciji s drugim antibioticima (najčešće $\beta$-laktamskim antibioticima) kako bi se postigao sinergistički učinak ili proširio spektar antimikrobne aktivnosti. U 2015. godini postotak prodaje aminoglikozida u 30 članica EU iznosila je 3,5\%. Postoje značajne razlike u prodaji aminoglikozida između različitih zemalja EU, te su najniže stope prodaje zabilježene u skandinavskim zemljama, a najviše u Španjolskoj. Šesta su najčešće upotrijebljena antimikrobna skupina nakon tetraciklina, penicilina, sulfonamida, makrolida i polimiksina (EMA/ESVAC, 2017).

EMA je u izvještaju o prodaji antimikrobnih veterinarskih lijekova za 29 članica EU i Švicarsku prikazala trendove prodaje lijekova u razdoblju od 2010. do 2015. (EMA, 2017). U 2015. godini se u Hrvatskoj prodalo ukupno 27,9 tona farmakoloških djelatnih tvari za primjenu u životinja za hranu. Zabilježen je pad prodaje aminoglikozida u 2015. u odnosu na 2014. sa $8 \mathrm{mg} / \mathrm{PCU}$ na $6,5 \mathrm{mg} / \mathrm{PCU}$. 


\section{Negativni učinci ostataka aminoglikozida}

Prekomjerna upotreba, zloupotreba ili nedostatak kontrole u primjeni antibiotika rezultira njihovom visokom razinom akumulacije u organizmu životinja (Ronquillo i Hernandez, 2017). Upotreba antibiotika kao promotora rasta također dovodi do pojave potencijalno štetnih ostataka u mesu i ostalim prehrambenim proizvodima životinjskog podrijetla. Ostaci antimikrobnih lijekova koji su iznad propisane koncentracije utvrđenim od strane FDA-a (tolerancije), EMA ili JECFA (Joint FAO/WHO Expert Commitee on Food Additives) (NDK) mogu rezultirati razvitkom alergijskih reakcija, karcinoma, i/ ili poremećajima ravnoteže intestinalne mikrobiote i razvitkom antimikrobne rezistencije kod bakterija što otežava liječenje infekcija kod ljudi. Aminoglikozidni antibiotici mogu uzrokovati ototoksičnost i nefrotoksičnost, no to se obično događa samo ako se radi o učestaloj primjeni (Baynes i sur., 2016). Rice i sur. (1983) izvijestili su o toksikološkim učincima linkomicina prisutnog u mliječnim proizvodima, a zahvaćene krave su razvile anoreksiju, proljev i ketozu. Pereira i sur. (2014) su procijenili učinak uporabe antimikrobnih supstancija na učestalost pojave antibiotičke rezistencije kod bakterijskog soja Escherichia coli izoliranog iz fecesa teladi te se ustvrdilo da su bakterijski sojevi iz uzoraka uzetih od teladi tretiranih s enrofloksacinom imali veću vjerojatnost $(\mathrm{P}<0,0001)$ da budu rezistentni na fluorokinolone. Ovi su rezultati osobito uznemirujući jer su ti antibiotici ključni u humanoj medicini za liječenje bolesti uzrokovanih nekom od bakterija iz rodova Salmonella, Campylobacter i Shigella (Collignon i sur., 2009). Antibiotici koji se koriste u suzbijanju uzročnika mastitisa su najčešći antimikrobni agensi koji se koriste u uzgoju mliječnih krava (Fisher i sur., 2011).

Posljedice korištenja antibiotika u ishrani životinja obuhvaća kompleksni sustav međusobno povezanih procesa: razvitak rezistentnih bakterija, prijenos ostataka antibiotika, rezistentnih bakterija i gena za rezistenciju s proizvoda životinjskog podrijetla na potrošače (Aminov, 2009; Chee-Sanford, 2009). Prisutnost ostataka antibiotika u okolišu ne mijenja samo strukturu i raznolikost mikrobiološke zajednice tla, nego utječe i na svojstvo prisutnih mikroorganizama da razgrađuju kontaminante te obavljaju druge funkcije poput metanogeneze, transformacije dušičnih spojeva i smanjenje razine sulfata $\mathrm{u}$ tlu i vodenom okolišu (Keen i Patrick, 2013). Ograničavanje potrošnje antibiotika je najizravnija strategija za suzbijanje širenja ostataka antibiotika okolišem i antibiotičke rezistencije (slika 1). Povijesni primjeri podupiru pretpostavku da učestalost pojave otpornosti na antibiotike kod bakterija opada kada se antibiotici više ne primjenjuju za poticanje rasta životinja. Tako je danska vlada 1995. godine zabranila uporabu avoparcina, što je rezultiralo smanjenjem učestalosti pojave rezistentnih sojeva E. faecium s 72,7\% 1995. na 5,8\% 2000. godine (Aarestrup i sur., 2001).

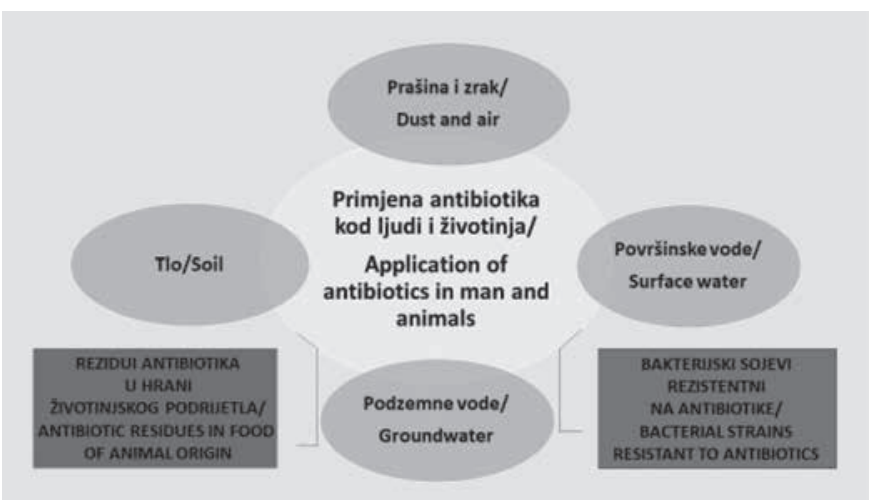

Slika 1. Prisutnost ostataka antibiotika u okolišu i hrani životinjskog podrijetla i širenje bakterija rezistentnih na antibiotike kao posljedica pretjerane uporabe antibiotika kod ljudi i životinja

Figure 1. Presence of antibiotic residues in environment and in food of animal origin, and spreading of bacteria resistant to antibiotics as a consequence of redundant use of antibiotics in man and animals

\section{Mehanizmi rezistencije na aminoglikozide}

Bakterijska otpornost na antibiotike postala je ozbiljna i sve veća prijetnja modernoj medicini te se pojavila kao jedan od vodećih zdravstvenih problema 21. stoljeća (WHO, 2014). Procjenjuje se da će se do 2050. godine povećati razina antimikrobne otpornosti (AMR, engl. antimicrobial resistance) zbog čega će do 10 milijuna ljudi godišnje umirati, a ujedno će doći do smanjenja BDP-a za 2 do 3,5\% (Pikkemaat i sur., 2016). Upotreba antibiotika u uzgoju životinja znatno pridonosi razvoju i širenju otpornosti na antibiotike kod bakterija prisutnih u intestinalnom traktu životinja čiji se geni za antibiotičku rezistenciju mogu prenijeti preko hrane životinjskog podrijetla na ljude (EFSA, 2015). Široko rasprostranjena subterapijska upotreba antibiotika kao promotora rasta kod životinja je pogodovala širenju i uspostavljanju stabilnih rezistentnih sojeva $\mathrm{u}$ okolišu, te stoga primjena antibiotika koja nije u terapijske svrhe, više nije prihvaćena unutar EU (EC, 2003). Otpornost na aminoglikozide kod bakterija može biti urođena ili stečena. Budući da se aminoglikozidi transportiraju kroz staničnu membranu u energetski ovisnom procesu, koji zahtijeva prisutnost kisika, anaerobne bakterije su urođeno otporne na aminoglikozide. Drugi mikroorganizmi, poput streptokoka i enterokoka, čija stanična stijenka služi kao barijera, također imaju urođenu otpornost na aminoglikozide. Razumijevanje genetičke osnove urođene otpornosti bakterija na aminoglikozide može dovesti do razvoja novih kombinacija antibiotika u svrhu poboljšanja ili proširivanja aktivnosti antibiotika prema ciljnim patogenima (Blair i sur. 2015). Mehanizmi rezistencije složeni su, te se razlikuju za pojedine aminoglikozide i različiti su kod pojednih bakterijskih vrsta. Mnogi geni za rezistenciju nalaze se na pokretnim genetičkim elementima povećavajući vjerojatnost širenja otpornosti na aminoglikozide (Ramirez i Tolmasky, 2010). Otpornost bakterija na antibiotike obuhvaća više različitih mehanizma koji se mogu svrstati u tri glavne grupe: a) smanjenje intracelularne koncentracije antibiotika zbog promjene permeabilnosti vanjske membrane i/ili učinkovitih "efflux" mehanizama; b) modifikacija ciljnog mjesta 
djelovanja antibiotika zbog genetičke mutacije ili post-translacijske modifikacije ciljnog mjesta djelovanja; c) inakitvacija antibiotika uzorkovana enzimskom modifikacijom antibiotika.

Kao posebni mehanizam rezistencije navodi se i mijenjanje inhibiranog metaboličkog puta (Džidić i sur., 2008, Blair i sur. 2015). Razumijevanje mehanizama antibiotičke rezistencije i poznavanje metaboličkih puteva biosinteze antibiotika na molekularnoj razini omogućava razvoj novih antibiotika, zahvaljujući i značajnom napretku u razvoju raznovrsnih pristupa metaboličkog inženjerstva i sintetičke biologije (Petković i sur., 2017).

Smanjenje intracelularne koncentracije antibiotika može biti posljedica smanjenog unosa lijeka ili djelovanja aktivnih "efflux" mehanizama, kao npr. rezistencija na gentamicin koja je uzrokovana inaktivacijom porina vanjske membrane, ustanovljena kod nekih vrsta iz rodova Pseudomonas, Burkholderia, Stenotrophomonas, kao i kod nekih bakterijskih sojeva koje pripadaju vrstama E.coli, Lactococcus lactis i Acinetobacter baumanii (Poole, 2005).

Otpornost na aminoglikozide najčešće je rezultat aktivnosti enzima koji modificiraju antibiotike djelovanjem fosfotransferaza, acetiltransferaza i adeniltransferaza. Ovi enzimi modificiraju hidroksilne ili amino skupine 2-deoksistreptaminske jezgre, te njene šećerne komponente čime onemogućavaju vezanje aminoglikozida na ciljano mjesto unutar stanice. Bakterijski sojevi, producenti aminoglikozidnih antibiotka, se zaštićuju od njihove antimikrobne aktivnosti djelovanjem enzima koji dodaju metilnu skupinu na specifične nukleotide u 16S rRNA koji su neophodni za vezanje aminoglikozida, čime se inhibira njihov antibiotički učinak bez ometanja drugih ribosomskih funkcija. Metilacija ciljnog mjesta djelovanja na ribosomu je također rastući mehanizam rezistencije kod klinički relevantnih Gram-negativnih bakterija. Prvi gen koji je identificiran bio je gen koji kodira za 16S rRNA metilazu, armA (Galimand i sur., 2003). Nakon toga je objavljeno još 9 dodatnih gena koji kodiraju za metilaze odgovorne za antibiotičku rezistenciju: $r m t A, r m t B$, $r m t C, r m t D, r t m D 2, r m t E, r m t F, r m t G$ i $n p m A$ (Potron i sur., 2015). Geni koji kodiraju za ove determinante obično se nalaze na pokretnim genetičkim elementima zajedno s genima koji uzrokuju otpornost bakterija na druge skupine antibiotika. Geni $r m t A, r m t B, r m t C, r m t D, r t m D 2, r m t E, r m t F, r m t G$ uzrokuju rezistenciju na gentamicin, tobramicin, kanamicin i amikacin, dok gen пртA uzrokuje rezistenciju na gentamicin, tobramicin, kanamicin, amikacin, neomicin i apramicin, ali ne i na streptomicin (Garneau-Tsodikova i Labby, 2016).

Formiranje bakterijskog biofilma je specifični mehanizam otpornosti patogena koji se ispoljio kao glavni problem u tretmanu kroničnih infekcija, posebno onih uzrokovanih Gram-negativnim patogenima (Meyer, 2005; Rice, 2006). Ustanovljeno je da subterapijske doze aminoglikozidnih antibiotika mogu inducirati formiranje biofilma kod patogenih sojeva Pseudomonas aeruginosa i Escherichia coli (Hoffman i sur., 2005).

\section{Kontrola aminoglikozida u hrani}

Ostatke aminoglikozida u hrani životinjskog podrijetla članice EU kontroliraju u okviru nacionalnih planova praćenja ostataka veterinarskih lijekova koji su propisani Direktivom Vijeća 96/23/EZ (EC, 1996). Ovom direktivom definirani su postupci za države članice EU za usvajanjem i provođenjem nacionalnih planova praćenja ostataka veterinarskih lijekova u životinjama koje se koriste za proizvodnju hrane. Direktiva utvrđuje razine i učestalost uzorkovanja za goveda, ovce, koze, svinje, konjiće, perad, akvakulture, mlijeko, jaja, meso kunića i divljači, med, kao i skupine tvari koja se prati za svaku vrstu hrane. Dvije glavne skupine ostataka koje treba pratiti sukladno Direktivi Vijeća 96/23/EZ su skupina A koju čine tvari koje imaju anabolički učinak i neovlaštene tvari (npr. steroidi), te skupina B, veterinarski lijekovi i kontaminanti gdje antibiotici čine skupinu B1.

Određivanje, odnosno detekcija tvari iz skupine A i B prema Direktivi Vijeća 96/23/EZ, se često ne ograničava samo na osnovnu supstancu, već se analiziraju jedan ili više nastalih metabolita (De Brabander i sur., 2009). Metode analize antimikrobnih lijekova mogu se grupirati u različite kategorije: mikrobiološke, imuno-kemijske ili fizikalno-kemijske (De Brabander i sur., 2009, Makovec i sur. 2014). Mikrobiološke metode se oslanjaju na zajedničko svojstvo svih antibakterijskih spojeva, kao što je inhibicija rasta mikroorganizama (Šušković i Kos, 2017). Imuno-kemijske metode uključuju imuno-analize npr. ELISA (eng. enzyme-linked immunosorbent assay) i EIA (eng. enzyme immunoassay) testove za određivanje ostataka streptomicina i imuno-afinitetnu kromatografiju (Gačić i sur. 2015). Fizikalno-kemijske metode temelje se na kromatografskom pročišćavanju/razdvajanju ostataka nakon čega slijedi spektroskopska kvantifikacija putem UV, fluorescentne ili MS detekcije (De Brabander i sur., 2009; EFSA, 2011). Metode za nadziranje veterinarsko-medicinskih proizvoda skupine tvari B dijele se na orijentacijske (eng. screening methods) i potvrdne metode (eng. confirmatory methods). Orijentacijske metode se koriste za otkrivanje prisutnosti analita ili klase analita na razini od interesa, dok potvrdne metode pružaju potpune ili komplementarne informacije kako bi se analit nedvosmisleno identificirao. Potvrdne metode moraju se temeljiti na primjeni spektrometrije masa (npr. GC-MS, LC-MS) te moraju ispunjavati kriterije navedene u Odluci Komisije 2002/657/EZ (EC, 2002a).

Brojne potvrdne kromatografske metode razvijene su za kvantifikaciju aminoglikozida u životinjskim tkivima, poput plinske kromatografije s masenom detekcijom (GC-MS), tekućinske kromatografije s fluorescentnom (LC-FLD) ili masenom detekcijom (LC-MS) te tankoslojna kromatografija (TLC) fragmenata nastalih kemijskom razgradnjom (Stolker i Brinkman, 2005, Kos, 2017). Aminoglikozidi su slabo hlapljivi spojevi usljed čega je njihova analiza primjenom plinske kromatografije otežana (Solomun Kolanović i sur., 2011). Kvantifikacija ostataka aminoglikozida najčešće se provodi tekućinskom kromatografijom kombiniranom $\mathrm{s}$ tandemskom spektrometrijom masa - LC-MS/MS (Delatour i sur. 2018.; Desmarchelier i sur., 2018). Zbog polarnosti molekula aminoglikozida, ekstrakcija i kromatografska separacija primjenom kromatografije obratnih faza je otežana pa se primjenjuju derivatizacijski postupci (Posyniak i sur., 2001). Također se primjenjuju postupci ionizacije molekula pri atmosferskom tlaku koji omogućuje analizu nehlapljivih spojeva bez dugotrajnog postupka derivatizacije. Obzirom na hidrofilnost ovih spojeva razvijen je postupak hidrofilne interakcije s masenom detekcijom uz primjenu kolona s kopolimernim adsorbensom (Zhu i suradnici, 2008). Sve se više primjenjuju metode koje omogućavaju istovremenu analizu ostataka antibiotika koji pripadaju različitim skupinama, 
uključujući i aminoglikozide (eng. multiresidue methods) (El Hawari i sur., 2017). U tablici 2 su navedene reference u koji- ma su primjenom takvih metoda analizirani ostaci aminoglikozida i drugih antibiotika u hrani životinjskog podrijetla.

Tablica 2. Metode za istovremenu analizu ostataka različitih skupina antibiotika (eng. multiresidue methods), tekućinske kromatografije kombinirane $s$ tandemskom spektrometrijom masa (LC-MS/MS), za određivanje ostataka aminoglikozida $i$ drugih antibiotika u hrani životinjskog podrijetla.

Table 2. Multiresidue methods of liquid chromatography - tandem mass specrometry (LC-MS/MS) for the determination of aminoglycosides and other residues of antibiotics in various food matrices of animal origin

\begin{tabular}{|c|c|}
\hline Ostaci antibiotika određivani LC-MS/MS metodom & Referenca \\
\hline $\begin{array}{l}\text { avermektini, benzimidazoli, } \beta \text {-laktami, kinoloni, makrolidi, pirimidini, sulfonamidi, tetracikli- } \\
\text { ni }\end{array}$ & Ortelli i sur., 2009 \\
\hline $\begin{array}{l}\text { ampicilin, bacitracin A, eritromicin A, klaritromicin, klortetraciklin, kloramfenikol, monenzin } \\
\text { A, oksitetraciklin, penicilin } \mathrm{G} \text {, streptomicin, tetraciklini, tilozin A, virginiamicin M1 }\end{array}$ & De Alwis i Heller, 2010 \\
\hline aminoglikozidi & Almeida i sur., 2012 \\
\hline $\begin{array}{l}\text { benzimidazoli, kinoloni, nitroimidazoli, } \beta \text {-laktami, makrolidi, trifenilmetanske boje, sulfona- } \\
\text { midi i tetraciklini }\end{array}$ & Biselli i sur., 2013 \\
\hline $\begin{array}{l}\text { avermektini, amfenikoli, benzimidazoli, } \beta \text {-laktami, kinoloni, makrolidi, ionofore, pirimidini, } \\
\text { sulfonamidi, tetraciklini }\end{array}$ & Robert i sur., 2013 \\
\hline aminoglikozidi & Bohm i sur., 2014 \\
\hline fluorkinoloni, kinoloni, sulfonamidi, tetraciklini & Martins i sur., 2015 \\
\hline $\begin{array}{l}\text { aminokumarini, amfenikoli, benzimidazoli, -laktami, diaminopirimidini, kinoloni, linkozamdi, } \\
\text { makrolidi, pleuromutilini, sulfonamidi, streptogramini, polipeptidi kinoksalini, tetraciklini }\end{array}$ & Robert i sur., 2015 \\
\hline aminoglikozidi, linkozamidi, makrolidi, sulfonamidi, tetraciklini & El Hawari i sur., 2017 \\
\hline aminoglikozidi & Asakawa i sur., 2018 \\
\hline $\begin{array}{l}\text { amfenikoli, avermektini, diaminopirimidini, benzimidazoli, kokcidiostatici, kinoloni, linkoza- } \\
\text { midi, makrolidi, rifamicini, sulfonamidi }\end{array}$ & Desmarchelier i sur., 2018 \\
\hline aminoglikozidi & Savoy i sur., 2018 \\
\hline
\end{tabular}

Procjenu rizika i određivanje NDK za antibiotike u prehrambenim proizvodima životinjskog podrijetla, kao što su mišići, jetra, bubreg, masno tkivo, mlijeko i jaja, u SAD-u određuje Uprava za hranu i lijekove (FDA), dok je ekvivalentno regulatorno tijelo u EU Europska agencija za lijekove (EMA). Komisija (EU) objavljuje NDK koje je odredio Odbor za veterinarsko-medicinske proizvode (CVMP - Committee for Medicinal Products for Veterinary Use). Postoje i nezavisna tijela za procjenu rizika, kao što je Zajednička agencija za hranu i poljoprivredu/Stručni odbor za prehrambene aditive Svjetske zdravstvene organizacije (JECFA, eng. The Joint FAO/WHO Expert Committee on Food Additives) koji također preporučuju NDK. Komisija Codex Alimentarius (CAC - Codex Alimentarius Commission) određuje hoće li se uspostaviti međunarodni standardi za ostatke veterinarskih lijekova (NDK). Ostaci antibiotika mogu imati negativne posljedice na zdravlje potrošača kada koncentracija ostataka u prehrambenim proizvodima prelazi granicu tolerancije tj. NDK. Mogući štetni učinci na zdravlje mogu uključivati alergijske reakcije, krvne diskrazije, karcinogenost i kardiovaskularnu toksičnost. Proces procjene rizika se temelji na provođenju mnogobrojnih sigurnosnih studija te in vitro studija u kojim se utvrđuje prihvatljiv dnevni unos (eng. Acceptable daily intake, ADI). ADI se zatim prilagođava vrijednostima potrošnje hrane za različite vrste tkiva (300 g za mišiće, $100 \mathrm{~g}$ za jetru, $50 \mathrm{~g}$ za bubrege, 50 g za masnoću, 1500 g za mlijeko) kako bi se determinirale granice tolerancije (NDK) za svaku vrstu tkiva.

Uredbom Komisije (EU) br. 37/2010 o farmakološki aktivnim supstancama i njihovoj klasifikaciji za sve vrste životinja koje se koriste za proizvodnju hrane definirane su NDK vrijednosti za aminoglikozidne antibiotike, kako je navedeno u tablici 3 (EC, 2010). 
Tablica 3. Najveće dopuštene količine (NDK) aminoglikozidnih antibiotika u hrani životinjskog podrijetla (EC, 2010).

Table 3. Maximum residue limits (MRL) of aminoglycosides in food of animal origin (EC, 2010).

\begin{tabular}{|c|c|c|c|c|c|c|c|}
\hline \multirow{3}{*}{ Aminoglikozidi } & \multirow{3}{*}{ Životinjska vrsta } & \multicolumn{6}{|c|}{ NDK $(\mu \mathrm{g} / \mathrm{kg})$} \\
\hline & & \multicolumn{4}{|l|}{ Tkivo } & \multirow[b]{2}{*}{ Mlijeko } & \multirow[b]{2}{*}{ Jaja } \\
\hline & & Mišić & Jetra & Bubreg & $\begin{array}{l}\text { Masno } \\
\text { tkivo }\end{array}$ & & \\
\hline \multirow{2}{*}{ Apramicin } & goveda & 1000 & 10000 & 20000 & 1000 & $\begin{array}{l}\text { Ne primjenjivati } \\
\text { kod životinja čije } \\
\text { se mlijeko koristi } \\
\text { za prehranu ljudi. }\end{array}$ & \\
\hline & $\begin{array}{l}\text { ovce, svinje, kokoši i } \\
\text { kunići }\end{array}$ & $\begin{array}{l}\text { Nije } \\
\text { primje- } \\
\text { njivo }\end{array}$ & $\begin{array}{l}\text { Nije pri- } \\
\text { mjenjivo }\end{array}$ & $\begin{array}{l}\text { Nije pri- } \\
\text { mjenjivo }\end{array}$ & $\begin{array}{l}\text { Nije pri- } \\
\text { mjenjivo }\end{array}$ & \multicolumn{2}{|c|}{$\begin{array}{l}\text { Ne primjenjivati kod životinja } \\
\text { čije se mlijeko ili jaja koriste za } \\
\text { prehranu ljudi. }\end{array}$} \\
\hline $\begin{array}{l}\text { Dihidrostrepto- } \\
\text { micin }\end{array}$ & $\begin{array}{l}\text { sve vrste preživača, } \\
\text { svinje i kunići }\end{array}$ & 500 & 500 & 1000 & 500 & 200 & \\
\hline Gentamicin & $\begin{array}{l}\text { sve vrste sisavaca } \\
\text { koje se koriste za } \\
\text { proizvodnju hrane te } \\
\text { ribe }\end{array}$ & 50 & 200 & 750 & 50 & 100 & \\
\hline Neomicin & $\begin{array}{l}\text { sve vrste životinja } \\
\text { koje se koriste za } \\
\text { proizvodnju hrane }\end{array}$ & 500 & 5500 & 9000 & 500 & 1500 & 500 \\
\hline Kanamicin & $\begin{array}{l}\text { sve vrste životinja } \\
\text { koje se koriste za } \\
\text { proizvodnju hrane } \\
\text { osim riba }\end{array}$ & 100 & 600 & 2500 & 100 & 150 & \\
\hline Paromomicin & $\begin{array}{l}\text { sve vrste životinja } \\
\text { koje se koriste za } \\
\text { proizvodnju hrane }\end{array}$ & 500 & 1500 & 1500 & & \multicolumn{2}{|c|}{$\begin{array}{l}\text { Ne primjenjivati kod životinja } \\
\text { čije se mlijeko ili jaja koriste za } \\
\text { prehranu ljudi. }\end{array}$} \\
\hline Streptomicin & $\begin{array}{l}\text { sve vrste preživača, } \\
\text { svinje i kunići }\end{array}$ & 500 & 500 & 1000 & 500 & 200 & \\
\hline & ovce & 300 & 2000 & 5000 & 500 & 200 & \multirow{2}{*}{$\begin{array}{l}\text { Ne primje- } \\
\text { njivati kod } \\
\text { životinja } \\
\text { čija se jaja } \\
\text { koriste za } \\
\text { prehranu } \\
\text { ljudi. }\end{array}$} \\
\hline Spektinomicin & $\begin{array}{l}\text { sve ostale vrste živo- } \\
\text { tinja koje se koriste } \\
\text { za proizvodnju hrane }\end{array}$ & 300 & 1000 & 5000 & 500 & 200 & \\
\hline
\end{tabular}

\section{Rezultati kontrole aminoglikozida u EU}

Na temelju prikupljenih podataka iz svih članica EU, EFSA EMA i ECDC, objedinjuje rezultate nacionalnih planova i ostalih uzorkovanja načinjenih prema Direktivi Vijeća 96/23/EZ i objedinjuje ih u jedan izvještaj. U razdoblju od četiri godine (2013. - 2016.) prijavljeno je ukupno 249 nesukladnih rezultata sa povišenim koncentracijama aminoglikozida (EFSA, 2015, 2016, 2017, 2018). Nesukladni rezultati utvrđeni za dihidrostreptomicin, streptomicin, gentamicin, kanamicin, neomicin i spektinomicin u tkivima različitih vrsta životinja, uključujući i mlijeko za razdoblje 2013.-2016. prikazani su u tablici 4. U 2013. godini utvrđen je najveći broj nesukladnih rezultata (ukupno 78). U četverogodišnjem razdoblju najveći broj nesukladnih rezultata od $136(54,6 \%)$ odnosio se na dihi- drostreptomicin, zatim 52 (20,9\%) na gentamicin, 35 (14,1\%) na neomicin, $24(9,64 \%)$ na spektinomicin, te je nađen po jedan nesukladan uzorak na kanamicin i streptomicin. Obzirom na vrstu životinjskog mesa najveći broj nesukladnih rezultata od $53,4 \%$ je utvrđen za goveđa tkiva, dok se $28,1 \%$ odnosilo na svinjska tkiva, a 6,02\% na perad, 3,61\% na ovce i koze, te svega $0,4 \%$ na konje. U uzorcima mlijeka određena su 2 nesukladna rezultata na gentamicin i jedan na kanamicin.

Tijekom istraživanja ostataka aminoglikozida u uzorcima mlijeka u kojima je ustanovljena prisutnost ostataka aminoglikozidnih antibiotika, u okviru „Nacionalnog plana monitoringa rezidua Republike Hrvatske“, u razdoblju od 2008. do 2010. godine, koncentracije gentamicina kretale su se u rasponu od 0,05 do $13,4 \mu \mathrm{g} / \mathrm{kg}$, neomicina od 2,38 do $1453,3 \mu \mathrm{g} / \mathrm{kg}$ te streptomicina od 0,18 do 67,2 $\mu \mathrm{g} / \mathrm{kg}$ (Bilandžić i sur., 2011). 
Tablica 4. Nesukladni rezultati (veće razine od propisanih NDK vrijednosti) ostataka aminoglikozidnih antibiotika dobiveni u okviru nacionalnih programa praćenja ostataka veterinarskih lijekova i dodatnih uzorkovanja članica EU u razdoblju 2013.-2016. (EFSA, 2015; EFSA 2016; EFSA, 2017)

Table 4. Non-compliant results (exceeded the prescribed MRL levels) of aminoglycoside residues obtained in the frame of national residue monitoring programs, including additional sampling of EU members for the period 2013-2016

\begin{tabular}{|c|c|c|c|c|c|c|c|c|}
\hline Godina & $\begin{array}{l}\text { Vrsta } \\
\text { životinje }\end{array}$ & $\begin{array}{l}\text { Dihidro- } \\
\text { streptomicin }\end{array}$ & $\begin{array}{l}\text { Gentami- } \\
\text { cin }\end{array}$ & Kanamicin & Neomicin & $\begin{array}{l}\text { Spektino- } \\
\text { micin }\end{array}$ & $\begin{array}{l}\text { Streptomi- } \\
\text { cin }\end{array}$ & Ukupno \\
\hline \multirow{6}{*}{2016} & govedo & 19 & 9 & & 9 & 3 & & 40 \\
\hline & svinja & 9 & 2 & & 1 & 2 & & 14 \\
\hline & $\begin{array}{l}\text { ovce/ } \\
\text { koze }\end{array}$ & 2 & & & & & & 2 \\
\hline & perad & & & & & 13 & & 13 \\
\hline & mlijeko & & 2 & & & & & 2 \\
\hline & Ukupno & 30 & 13 & & 10 & 18 & & 71 \\
\hline \multirow{5}{*}{2015} & govedo & 22 & 12 & & 1 & & 1 & 36 \\
\hline & svinja & 13 & 3 & & & 1 & & 17 \\
\hline & $\begin{array}{l}\text { ovce/ } \\
\text { koze }\end{array}$ & 1 & & & & & & 1 \\
\hline & mlijeko & & & 1 & & & & 1 \\
\hline & Ukupno & 36 & 15 & 1 & 1 & 1 & 1 & 55 \\
\hline \multirow{7}{*}{2014} & govedo & 12 & 7 & & 7 & 5 & & 31 \\
\hline & svinja & 11 & 2 & & & & & 13 \\
\hline & $\begin{array}{l}\text { ovce/ } \\
\text { koze }\end{array}$ & 3 & & & & & & 3 \\
\hline & perad & 1 & & & & & & 1 \\
\hline & konj & 1 & & & & & & 1 \\
\hline & mlijeko & 1 & & & & & & 1 \\
\hline & Ukupno & 29 & 9 & & 7 & 5 & & 50 \\
\hline \multirow{5}{*}{2013} & govedo & 17 & 13 & & 13 & & & 43 \\
\hline & svinja & 22 & 2 & & 2 & & & 26 \\
\hline & $\begin{array}{l}\text { ovce/ } \\
\text { koze }\end{array}$ & 1 & & & 2 & & & 3 \\
\hline & perad & 1 & & & & & & 1 \\
\hline & Ukupno & 41 & 15 & & 17 & & & 73 \\
\hline \multicolumn{2}{|c|}{ Ukupno svi } & 136 & 52 & 1 & 35 & 24 & 1 & 249 \\
\hline
\end{tabular}

Članice EU koriste centralni sustav brzog uzbunjivanja za hranu i hranu za životinje RASFF (eng. Rapid Alert System for Food and Feed) kojim prijavljuju nesukladne rezultate određivanja aminoglikozida u kontroli različitih proizvoda koji dolaze na tržište EU (EC, 2002b). U razdoblju od 2002. do 2018. godine prijavljeno je ukupno 11 proizvoda s nesukladnim koncentracijama aminoglikozida, odnosno 3 goveđa mesa, jedno konjsko meso, meso zmije, svinjska crijeva, dva uzorka ribe, jedni škampi, te jedan enzimski premiks i jedna hrana za životinje (RASFF, 2018). Najviša koncentracija ostataka aminoglikozida od $56200 \mu \mathrm{g} / \mathrm{kg}$ određena je za dihidrostreptomicin u goveđem mesu iz Poljske 2011. godine, dok je 2007. godine prijavljena nedozvoljena koncentracija dihidrostreptomicina u goveđem mesu iz Italije. U uzorcima svinjskih crijeva podrijetlom iz Brazila, analiziranih u Francuskoj u 2009. godini, izmjerena je koncentracija ostataka dihidrostreptomicina od 
$787 \mu \mathrm{g} / \mathrm{kg}$, a isti antibiotik je bio prisutan i u konjskom mesu iznad dozvoljene koncentracije $(19,22 \mu \mathrm{g} / \mathrm{kg})$ što je prijavljeno u Mađarskoj 2014. godine. U Češkoj je Republici 2010. godine određena nedozvoljena koncentracija ostataka neomicina $\mathrm{u}$ rasponu od 656 do $1385 \mu \mathrm{g} / \mathrm{kg}$ u uzorcima ribe Pangasius hypophthalmus podrijetlom iz Vijetnama, dok su škampi s Filipina sadržavali ostatke streptomicina u nedozvoljenoj koncentraciji, prema analizi iz Španjolske 2003. godine. Nedozvoljeni ostatci kanamicina su određeni u mesu pitona, podrijetlom iz Vijetnama, u koncentraciji od $2718 \mu \mathrm{g} / \mathrm{kg}$, što je prijavljeno u Njemačkoj, a ostatci istog antibiotika, ali u manjoj koncentraciji $(15 \mu \mathrm{g} / \mathrm{kg})$ pronađeni su u enzimskom premiksu podrijetlom iz Njemačke, a prijavljeni su u Belgiji. Nedozvoljena koncentracija apramicina određena je u Sloveniji 2004. godine, u hrani za životinje u koncentraciji od 122 mg/kg. U 2017. je godini u Italiji određen nesukladan rezultat ostataka spektinomicina u govedini.

\section{Zaključci}

Budući da lijekovi iz skupine aminoglikozida imaju široki spektar i učinkovito djelovanje prema Gram-negativnim bakterijama, često se primjenjuju u uzgoju životinja. Uslijed nepravilne primjene i nepoštivanja vremena karence, u mesu i ostalim prehrambenim proizvodima životinjskog porijekla mogu se pojaviti ostaci aminoglikozida u količinama većim od dozvoljenih ili preporučenih zakonodavstvom, za koje se, zbog utjecaja na razvoj antibiotičke rezistencije i pojave alergija i drugih zdravstvenih poremećaja, smatra da su štetni za potrošača. Učestala primjena kod potrošača može dovesti čak i do razvoja ototoksičnosti i nefrotoksičnosti. Kako bi se izbjegli negativni utjecaji ostataka na zdravlje potrošača i proizvela zdravstveno ispravna hrana nužna je učinkovita kontrola aminoglikozida u hrani životinjskog podrijetla provođenjem nacionalnih planova praćenja ostataka, koji podrazumijevaju primjenu osjetljivih, točnih i preciznih kvantitativnih metoda koje preporučaju regulatorna tijela za određivanje veterinarskih lijekova.

Prema izvještaju Europske agencije za sigurnost hrane (EFSA) o rezultatima praćenja aminoglikozida u državama članicama Europske Unije za četverogodišnje razdoblje (2013.-2016.), zabilježena je prisutnost aminoglikozida u razinama većim od dozvoljenih u čak 249 analiziranih uzoraka, s najvećim brojem nesukladnih uzoraka na dihidrostreptomicin i gentamicin, koji su pronađeni u goveđem i svinjskom mesu.

\section{Literatura}

Aarestrup, F. M., Seyfarth, A. M., Emborg, H. D., Pedersen, K., Hendriksen, R. S., Bager, F. (2001) Effect of abolishment of the use of antimicrobial agents for growth promotion on occurrence of antimicrobial resistance in fecal enterococci from food animals in Denmark. Antimicrobal Agents and Chemotherapy, 45 2054-2059.

Almeida, M. P., Rezende, C. P., Souza, L. F., Brito, R. B. (2012) Validation of a quantitative and confirmatory method for residue analysis of aminoglycoside antibiotics in poultry, bovine, equine and swine kidney through liquid chromatography-tandem mass spectrometry. Food Additives \& Contaminants A, 29 517-525.

Aminov, R. I. (2009) The role of antibiotics and antibiotic resistance in nature. Environmental Microbiology, 11 (12) 2970-2988.

Arikan, O. A., Mulbry, W., Rice, C. (2009) Management of antibiotic residues from agricultural sources: use of composting to reduce chlortetracycline residues in beef manure from treated animals. Journal of Hazardous Materials, 164 483-489.

Asakawa, D., Uemura, M., Sakiyama, T., Yamano, T. (2018) Sensitivity enhancement of aminoglycosides in hydrophilic interaction liquid chromatography with tandem mass spectrometry by post-column addition of trace sodium acetate in methanol. Food Additives \& Contaminants A, 35 1116-1126.

Baynes, R. E., Dedonder, K., Kissel, L., Mzyk, D., Marmulak, T., Smith, G., Tell, L., Gehring, R., Davis, J., Riviere, J. E. (2016) Health concerns and management of select veterinary drug residues. Food and Chemical Toxicology, 88 112122.

Bilandžić, N., Solomun Kolanović, B., Varenina, I., Scortichini, G., Brstilo, M., Rudan, N. (2011) Veterinary drug residues determination in raw milk in Croatia. Food Control, 22 1941-1948

Biselli, S., Schwalb, U., Meyer, A., Hartig, L. (2013) A multi-class, multi-analyte method for routine analysis of $84 \mathrm{ve}-$ terinary drugs in chicken muscle using simple extraction and LC-MS/MS. Food Additives \& Contaminants A, 30 921-939.

Blair, J.M.A., Webber, M.A., Baylay, A.J., Ogbolu, D. O. , Piddock, L. J. V. (2015) Molecular mechanisms of antibiotic resistance, Nature Reviews Microbiology, 13 42-51.

Bohm, D. A., Stachel, C. S., Gowik, P. (2014) Validation of a method for the determination of aminoglycosides in different matrices and species based on an in-house concept. Food Additives \& Contaminants A, 30 1037-1043.

Butaye, P., Devriese, L. A., Haesebrouck, F. (2003) Antimicrobial growth promoters used in animal feed: effects of less well known antibiotics on Gram-positive bacteria. Clinical Microbiology Reviews, 16 175-188.

De Alwis, H., Heller, D. N. (2010) Multiclass, multiresidue method for the detection of antibiotic residues in distillers grains by liquid chromatography and ion trap tandem mass spectrometry. Journal of Chromatography A, 1217 30763084.

De Brabander, H. F., Noppe, H., Verheyden, K., Bussche, J. V., Wille, K., Okerman, L., Vanhaecke, L., Reybroeck, W., Ooghe, S., Croubels, S. (2009) Residue analysis: Future trends from a historical perspective. Journal of Chromatography A, 1216 7964-7976.

Delatour, T., Racault, L., Bessaire, T., Desmarchelier, A. (2018) Screening of veterinary drug residues in food by LCMS/MS. Background and challenges. Food Additives \& Contaminants A, 35 632-645.

Gačić, M., Bilandžić, N., Ivanec Šipušić, Đ., Petrović, M., Kos, B., Vahčić, N., Šušković, J. (2015) Degradation of oxytetracycline, streptomycin, sulphathiazole and chloramphenicol residues in different types of honey, Food Technology and Biotechnology 53 (2) 154-162 
Desmarchelier, A., Fan, K., Tien, M. M., Savoy, M.-C., Tarres, A., Fuger, D., Goyon, A., Bessaire, T., Mottier, P. (2018) Determination of 105 antibiotic, anti-inflammatory, antiparasitic agents and tranquilizers by LC-MS/MS based on an acidic QuEChERS-like extraction. Food Additives \& Contaminants A, 35 646-660.

Diez, C., Guillarme, D., Spörri, A. S., Cognard, E., Ortelli, D., Edder, P., Rudaz, S. (2015) Aminoglycoside analysis in food of animal origin with a zwitterionic stationary phase and liquid chromatography-tandem mass spectrometry. Analytica Chimca Acta, 882 127-139.

Džidić, S., Šušković, J., Kos, B. (2008) Antibiotic resistance mechanisms in bacteria: biochemical and genetic aspects. Food Technology and Biotechnology, 46 11-21.

Castanon, J. I. R. (2007) History of the use of antibiotic as growth promoters in European poultry feeds. Poultry Science, 86 2466-2471.

Chee-Sanford, J. C., Mackie, R. I., Koike, S., Krapac, I. G., Lin. Y. F., Yannarell, A. C., Maxwell, S., Aminov, R. I. (2009) Fate and transport of antibiotic residues and antibiotic resistance genes following land application of manure waste. Journal of Environmental Quality, 38 (3) 1086-108.

Collignon, P., Powers, J. H., Chiller, T. M., Aidara-Kane, A., Aarestrup, F. M. (2009) World Health Organization ranking of antimicrobials according to their importance in human medicine: A critical step for developing risk management strategies for the use of antimicrobials in food production animals. Clinical Infectious Diseases, 49 (1) 132-141.

Džidić, S., Šušković, J., Kos, B. (2008): Antibiotic resistance mechanisms in bacteria: biochemical and genetic aspects. Food Technology and Biotechnology, 46 11-21.

EC (1996) Council Directive 96/23/EC of 29 of April 1996 on measures to monitor certain substances and residues thereof in live animals and animal products and repealing Directives 85/358/EEC and 86/469/EEC and Decisions 89/187/ EEC and 91/664/EEC. Official Journal of the European Union, L 125 10-32.

EC (2002a) Commission Decision 2002/657/EC of 12 August 2002 implementing Council Directive 96/23/EC concerning the performance of analytical methods and the interpretation of results. Official Journal of the European Union, L221, 8-28.

EC (2002b) Regulation (EC) No 178/2002 of the European parliament and of the council of 28 January 2002 laying down the general principles and requirements of food law, establishing the European Food Safety Authority and laying down procedures in matters of food safet. Official Journal of the European Union, L31 1-24.

EC (2003) Regulation No 1831/2003 of the European Parliament and of the Council of 22 September 2003 on additives for use in animal nutrition. Official Journal of the European Union, L268 1-29.

EC (2010) Council Regulation 37/2010/EU of 22 December 2009 on pharmacologically active substances and their classification regarding maximum residue limits in foodstuffs of animal origin. Official Journal of the European Union, L15 $1-72$.

EFSA (2015) Report for 2013 on the results from the monitoring of veterinary medicinal product residues and other su- bstances in live animals and animal product. EFSA Supporting publication 2015:EN-723.

EFSA (2016) Report for 2014 on the results from the monitoring of veterinary medicinal product residues and other substances in live animals and animal product. EFSA Supporting publication 2016:EN-923.

EFSA (2017) Report for 2015 on the results from the monitoring of veterinary medicinal product residues and other substances in live animals and animal product. EFSA Supporting publication 2017:EN-1150.

EFSA (2018) Report for 2016 on the results from the monitoring of veterinary medicinal product residues and other substances in live animals and animal product. EFSA Supporting publication 2018:EN-1358.

El Hawari, K., Mokh, S., Doumyati, S., Al Iskandarani, M., Verdon, E. (2017) Development and validation of a multiclass method for the determination of antibiotic residues in honey using liquid chromatography-tandem mass spectrometry. Food Additives \& Contaminants A, 34 582-597.

ECDC/EFSA/EMA (2015) First joint report on the integrated analysis of the consumption of antimicrobial agents and occurrence of antimicrobial resistance in bacteria from humans and food-producing animals (JIACRA). Dostupno na:

https://ecdc.europa.eu/sites/portal/files/media/en/publications/Publications/antimicrobial-resistance-JIACRA-report. pdf. Pristupljeno 07.08.2017.

EFSA (2011) Report for 2009 on the results from the monitoring of veterinary medicinal product residues and other substances in live animals and animal products. EFSA Journal, 158 1-70.

EFSA (2015) Report on antimicrobial resistance in zoonotic and indicator bacteria from humans, animals and food in 2013. EFSA Journal, 13 (2) 4036.

EMA (2014) European surveillance of veterinary antimicrobial consumption, sales of veterinary antimicrobial agents in 26 EU/EEA countries in 2012. Dostupno na: http:// www.ema.europa.eu/docs/en_GB/document_library/Report/2014/10/WC500175671.pdfPristupljeno: 21.07.2017.

EMA (2017) Sales of veterinary antimicrobial agents in 30 European countries in 2015. Trends from 2010 to 2015. Seventh ESVAC report. European Medicines Agency, EMA/184855/2017. Dostupno na:

http://www.ema.europa.eu/docs/en_GB/document_library/Report/2017/10/WC500236750.pdf

Pristupljeno: 20.07.2018.

EMA/ESVAC (2016) Sales of veterinary antimicrobial agents in 29 EU/EEA countries in 2014. Dostupno na:

http://www.ema.europa.eu/docs/en_GB/document_library/Report/2016/10/WC500214217.pdfPristupljeno: 27.07.2017.

EMA/ESVAC (2017) An agency of the European Union Sales of veterinary antimicrobial agents in 30 European countries in 2015. Dostupno na: www.ema.europa.eu/docs/en_GB/ document_library/Report/2017/.../WC500236750.pdf. Pristupljeno: 20.07.2018.

Fejzuli, L. (2017) Određivanje aminoglikozida u mlijeku LC-MS/MS metodom, Diplomski rad, Prehrambeno-biotehnološki fakultet Sveučilišta u Zagrebu.

Fisher, W. J., Schilter, B., Tritscher, A. M., Stadler, R. H. (2011) Environmental contaminants. U: Fuquay, J. W., Fox, P. 
F., McSweeney, P. L. H. (ed): Encyclopedia of dairy science, str. 898-905. Elsevier, London/New York, UK.

Galimand, M., Courvalin, P., Lambert, T. (2003) Plasmidmediated high-level resistance to aminoglycosides in Enterobacteriaceae due to $16 \mathrm{~S}$ rRNA methylation. Antimicrobial Agents and Chemotherapy, 47(8) 2565-2571.

Garneau-Tsodikova, S., Labby, K. J. (2016). Mechanisms of resistance to aminoglycoside antibiotics: overview and perspectives. Medicinal Chemistry Communication, 7 (1) 11-27.

Gilbert, D. N. (1995) Aminoglycosides. U: Mandell, G. L., Bennett, J. E., Dolin, R. (ed): Principles and Practice of Infectious Diseases, str. 279-306. Churchill Livingstone, New York, USA.

Hoffman, L. R., Argenio, D. A., MacCoss, M. J., Zhang, Z., Jones, R. A., Miller, S. I. (2005) Aminoglycoside antibiotics induce bacterial biofilm formation. Nature, 436 (25) $1171-1175$

Idowu, F., Junaid, K., Paul, A., Gabriel, O., Paul, A., Sati, N., Maryam, M., Jarlath, U. (2010) Antimicrobial screening of commercial eggs and determination of tetracycline residue using two microbiological methods. International Journal of Poultry Science, 9 959-962.

Keen, P.L., Patrick, D. M. (2013) Tracking change: A look at the ecological footprint of antibiotics and antimicrobial resistance. Antibiotics, 2 (2) 191-205.

Kos, B. (2017): predavanja iz modula "Ostatci antibiotika u hrani”, Prehrambeno-biotehnološki fakultet Sveučilišta u Zagrebu,

http://www.pbf.unizg.hr/hr/zavodi/zavod za biokemijsko_inzenjerstvo/laboratorij_za_tehnologiju_antibiotika_enzima_probiotika_i_starter_kultura/ostatci_antibiotika_u_hrani

Pristupljeno 22. srpnja 2018.

Kwon, S. I., Owens, G., Ok, Y. S., Lee, D. B., Jeon, W. T., Kim, J. G., Kim, K. R. (2011) Aplicabilitpy of the Charm II system for monitoring antibiotic residues in manure-based composts. Waste Management, 31 (1) 39-44.

Makovec, S., Kos, B., Šušković, J., Bilandžić, N. (2014) Tetraciklinski antibiotici i određivanje njihovih rezidua u hrani. Hrvatski časopis za prehrambenu tehnologiju, biotehnologiju i nutricionizam, 9 (1-2) 7-16.

Martins, M. T., Barreto, F., Hoff, R. B., Janka, L., Arsand, J B., Feijó, T. C., Schapoval, E. E. S. (2015) Determination of quinolones and fluoroquinolones, tetracyclines and sulfonamides in bovine, swine and poultry liver using LC-MS/MS. Food Additives \& Contaminants A, 32 333-341.

Meyer, A. L. (2005) Prospects and challenges of developing new agents for tough Gram-negatives. Current Opinion in Pharmacology, 5 490-494.

Ogle, J. M., Brodersen, D. E., Clemons, W. M. Jr., Tarry, M. J., Carter, A. P., Ramakrishnan, V. (2001) Recognition of cognate transfer RNA by the $30 \mathrm{~S}$ ribosomal subunit. Science, $292897-902$

Ogle, J. M., Ramakrishnan, V. (2005) Structural insights into translational fidelity. Annual Review of Biochemistry, 74 129-177.

Ortelli, D., Cognard, E., Jan, P., Edder, P. (2009) Comprehensive fast multiresidue screening of 150 veterinary drugs in milk by ultra-performance liquid chromatography coupled to time of flight mass spectrometry. Journal of Chromatography $B, 8772363-2374$
Ostermann, A., Siemens, J., Welp, G., Xue, Q., Lin X.Y., Liu X.J., Amelung W. (2013) Leaching of veterinary antibiotics in calcareous Chinese croplands. Chemosphere, 91 (7) 928-934.

Pereira, R. V., Siler, J. D., Ng, J. C., Davis, M. A., Grohn, Y. T., Warnick, L. D. (2014) Effect of on-farm use of antimicrobial drugs on resistance in fecal Escherichia coli of preweaned dairy calves. Journal of Dairy Science, 97 (12) 7644-7654.

Petković, H,. Lukežič, T., Šušković, J. (2017) Biosynthesis of Oxytetracycline by Streptomyces rimosus: Past, Present and Future Directions in the Development of Tetracycline Antibiotics, Food Technology and Biotechnology, 55 3-13.

Pikkemaat, M.G., Yassin, H., Van der Fels-Klerx, H. J., Berendsen, B. J. A. (2016) Antibiotic residues and resistance in the environment. RIKILT Wageningen University \& Research centre. Dostupno na: http://library.wur.nl/WebQuery/wurpubs/510717. Pristupljeno: 09.08.2017.

Poole, K. (2005) Efflux-mediated antimicrobial resistance. Journal of Antimicrobal Chemotherapy, 56 20-51.

Posyniak, A., Zmudzki, J., Niedzielska, J. (2001) Sample preparation for residue determination of gentamicin and neomycin by liquid chromatography. Journal of Chromatography $A, 914$ 59-66.

Potron, A., Poirel, L., Nordmann, P. (2015) Emerging broad-spectrum resistance in Pseudomonas aeruginosa and Acinetobacter baumannii: Mechanisms and epidemiology. International Journal of Antimicrobial Agents, 45 (6) 568 585.

Ramirez, M. S., Tolmasky, M. E. (2010) Aminoglycoside modifying enzymes. Drug Resistance Updates, 13 (6) 151-171.

RASFF (2018) Rapid alert system for food and feed (RASFF). Dostupno na: https://webgate.ec.europa.eu/rasffwindow/portal/?event=SearchForm\&cleanSearch $=1$. Pristupljeno 13.06.2018.

Rice, D. A., McMurray, C. H., Davidson, J. F. (1983) Ketosis in dairy cows caused by low levels of lincomycin in concentrate feed. Veterinary Record, 113 495-496.

Rice, L. B. (2006) Unmet medical needs in antibacterial therapy. Biochemical Pharmacolgy, 71 991-995.

Ristuccia, A. M., Cunha, B. A. (1982) The aminoglycosides. Medical Clinics of North America, 66 303-12.

Robert, C., Gillard, N., Brasseur, P. Y., Pierret, G., Ralet, N., Dubois, M., Delahaut, P. (2013) Rapid multi-residue and multi-class qualitative screening for veterinary drugs in foods of animal origin by UHPLC-MS/MS. Food Additives \& Contaminants A, 30 443-457.

Robert, C., Gillard, N., Brasseur, P. Y., Ralet, N., Dubois, M., Delahaut, P. (2015) Rapid multiresidue and multi-class screening for antibiotics and benzimidazoles in feed by ultra high performance liquid chromatography coupled to tandem mass spectrometry. Food Control, 50 509-515.

Ronquillo, M. G., Hernandez, J. C. A. (2017) Antibiotic and synthetic growth promoters in animal diets: Review of impact and analytical methods. Food Control, 72 255-267.

Savoy, M.-C., Woob, P. M., Ulricha, P., Tarresa, A., Mottiera, P., Desmarcheliera, A. (2018) Determination of 14 aminoglycosides by LC-MS/MS using molecularly imprinted polymer solid phase extraction for clean-up. Food Additives \& Contaminants A, 35 674-685. 
Solomun Kolanović, B., Đokić, M., Bilandžić, N., Varenina, I., Knežević, Z. (2011) Kromatografske metode za određivanje antibiotika u hrani životinjskog podrijetla - II dio. Veterinarska stanica, 41 (1) 25-37.

Spelman, D. W., McDonald, M., Spicer, W. J. (1989) Aminoglycoside antibiotic agents: A review. The Medical Journal of Australia, 151 346-349.

Stolker, A. A. M., Zuidema, T., Nielen, M. W. F. (2007) Residue analysis of veterinary drugs and growth-promoting agents. Trends in Analical Chemistry, 26 967-979.

Šušković, J., Kos, B. (2017) Biotehnologija 4: Biotehnološka proizvodnja lijekova (interna skripta, predavanja). Dostupno na: https://moodle.srce.hr/2017-2018/course/view. php?id=21286. Pristupljeno: 20.07.2018.

Šušković, J., Kos, B., Novak, J. (2017) Tehnologija antibiotika (interna skripta, predavanja). Dostupno na: https:// moodle.srce.hr/2017-2018/course/view.php?id=29048. Pristupljeno: 20.07.2018.

Taber, H. W., Mueller, J. P., Miller, P. F., Arrow, A. S. (1987) Bacterial uptake of aminoglycoside antibiotics. Microbiologial Reviwes, 51 (4) 439-547.

Vakulenko, S. B., Mobashery, S. (2003) Versatility of aminoglycosides and prospects for their future. Clinical Microbiological Reviwes, 16 430-450.

Van Boeckel, T. P., Brower, C., Gilbert, M., Grenfell, B. T., Levin, S. A., Robinsoni, T. P., Teillant, A., Laxminarayan, R. (2015) Global trends in antimicrobial use in food animals. Proceedings of the National Academy of Sciences of the United States of America, 112 (18) 5649-5654.

Van Landuyt, H. W., Boelaert, J., Glibert, B., Gordts, B., Verbruggen, A. (1986) Surveillance of aminoglycoside resistance. The Amrican Journal of Medicine, 80 76-81.

Vandenberge, V. (2012) Transfer of cross-contamination levels of coccidiostats, antibiotics and anthelmintics from feed to poultry matrices, $\mathrm{PhD}$ Thesis. Ghent University, Ghent, Belgium.

WHO (2014) Antimicrobial resistance: Global report on surveillance. Dostupno na: http://www.who.int/drugresistance. Pristupljeno: 30.08.2017.

Zingman, L. V., Park, S., Olson, T. M., Alekseev, A. E., Terzic, A. (2007) Aminoglycoside-induced translational readthrough in disease: overcoming nonsense mutations by pharmacogenetic therapy. Clinical Pharmacology \& Therapeutics, 81 99-103.

Zhu, W., Yang, J., Wei, W., Liu, Y., Zhang, S. (2008) Simultaneous determination of 13 aminoglycoside residues in foods of animal origin by liquid chromatography-electrospray ionization tandem mass spectrometry with two consecutive solid-phase extraction steps. Journal of Chromatography A, 1207 29-37. 